\title{
EVALUATION OF SORGHUM SILAGES OF DIFFERENT GENOTYPES WITH AND WITHOUT CONDENSED TANNINS
}

\author{
HELOISA CARNEIRO ${ }^{1}$, FAUSTO SOUZA SOBRINHO ${ }^{1}$, JOSÉ AVELINO SANTOS RODRIGUES ${ }^{2}$, \\ JOÃO EUSTÁQUIO CABRAL MIRANDA ${ }^{1}$ and SARAH SILVA BRUM ${ }^{3}$
}

\begin{abstract}
${ }^{1}$ Pesquisadores da Embrapa Gado de Leite. Rua Eugênio do Nascimento, 610, CEP 36038-330 Juiz de Fora, MG, Email:heloisa@cnpgl.embrapa.br, (autor paracorrespondência),fausto@cnpgl.embrapa.br,jecabral@cnpgl.embrapa.br ${ }^{2}$ Pesquisador da Embrapa Milho e Sorgo. Caixa Postal 151, CEP: 35701-970 Sete Lagoas, MG. avelino@cnpms.embrapa.br

${ }^{3}$ Estagiária da Embrapa Gado de Leite. Rua Eugênio do Nascimento, 610, CEP 36038-330 Juiz de Fora, MG. sarahsbrum@yahoo.com.br
\end{abstract}

Revista Brasileira de Milho e Sorgo, v.5, n.2, p.257-265, 2006

\begin{abstract}
A total of 10 Sorghum cultivar: two lines (CMSXS114, T ) and (CMSXS165, WT ), six hybrids (9953101,T; 9953130,T; BR601, WT; BR701, T; BR700, T; and AG2005, WT and two varieties (BR501, WT; and BR506, WT) with 8 replications were ensiled in PVC silos of $3 \mathrm{~kg}$ per silo for 60 days and then analyzed for condensed tannins (CT) (colorimetric analysis by the butanol- $\mathrm{HCl}$ method), $\mathrm{CP}, \mathrm{NDF}$, $\mathrm{ADF}$, and in vitro (IVDMD-24 and 48hs) digestibilities. Condensed tannins (CT) from quebracho were purified using affinity chromatography with sephadex LH-20 and used as a standard. Low concentrations of CT have been defined as $10 \mathrm{~g} \mathrm{~kg}^{-1} \mathrm{DM}$ or less and medium as 10 to $40 \mathrm{~g} \mathrm{~kg}^{-1} \mathrm{DM}$, and levels exceeding $40 \mathrm{~g} \mathrm{~kg}^{-1} \mathrm{DM}$ as high. Hybrid 9953130 had the highest concentration of CT among the sorghum silages $(\mathrm{P}<0.05)$, with $10.62 \mathrm{~g} \mathrm{~kg}^{-1} \mathrm{DM}$, and among the sorghum panicles, the hybrid 9953101 with 37.39 $\mathrm{g} \mathrm{kg}^{-1} \mathrm{DM}$. Differences among sorghum lines were not detected for lignin and in vitro digestibility $(\mathrm{P}>0.09)$. The highest $\mathrm{CP}$ content was noted for line CMSXS165 (97.4 g $\left.\mathrm{kg}^{-1} ; \mathrm{P}<0.05\right)$. Concentrations of CP in CMSXS114 (83.2 $\left.\mathrm{g} \mathrm{kg}^{-1}\right), \mathrm{BR} 700\left(76.4 \mathrm{~g} \mathrm{~kg}^{-1}\right)$, BR701 (80.5 $\left.\mathrm{g} \mathrm{kg}^{-1}\right)$, and AG2005 (79.2 $\left.\mathrm{g} \mathrm{kg}^{-1}\right)$ were above the overall mean $\left(74.0 \mathrm{~g} \mathrm{~kg}^{-1}\right)$. The in vitro digestibilities (24 and 48 hours) of the two isogenics lines CMSXS114 (T) and CMSXS165 (WT) were not different. We concluded that the CT level did not affect digestibility; however, relative CT concentrations were low. Therefore, we could not suggest significant effects of CT content on DM intake, digestibility levels or performance in cattle fed with any of these sorghum silages.
\end{abstract}

Key words: sorghum, silage, feed, crude protein, NDF, ADF, lignin and IVDMD

Abbreviation Key: $\mathbf{C T}=$ condensed tannin; $\mathbf{W T}=$ without tannin, $\mathbf{T}=\operatorname{tannin}$

\section{AVALIAÇÃO DE SILAGENS DE SORGO DE DIFERENTES GENÓTIPOS COM E SEM TANINO CONDENSADO}

RESUMO - Um total de dez cultivares, sendo duas linhagens de sorgo com (T) e sem tanino condensado (WT), CMSXS114 (T) e CMSXS165 (WT), seis híbridos, 9953101(T), 9953130(T), BR601 (WT), BR701 (T) BR700 (T) e AG2005 (WT), e duas variedades, BR 501(WT) e BR506 (WT), com oito repetições foram, ensiladas em silos de PVC, 
com capacidade de $3 \mathrm{~kg}$ por silo, por 60 dias, e analisadas para tanino condensado (TC) (análises colorimétricas, pelo método de butanol- $\mathrm{HCl})$, proteína bruta $(\mathrm{CP})$, fibra em detergente neutro (NDF), fibra em detergente ácido (ADF) e digestibilidade in vitro da matéria seca(DIVMS-24 e 48h). O tanino condensado (CT), extraído de quebracho purificado, foi utilizado como padrão (cromatografia com sephadex LH-20). Baixas concentrações de TC têm sido definidas na literatura pela concentração de $10 \mathrm{~g} \mathrm{~kg}^{-1} \mathrm{MS}$ ou menor. Valores médios são aqueles entre 10 e $40 \mathrm{~g} \mathrm{~kg}^{-1}$ na matéria seca e níveis acima de $40 \mathrm{~g} \mathrm{~kg}^{-1} \mathrm{MS}$ são considerados altos. O híbrido 9953130 apresentou a mais alta concentração de tanino condensado entre as silagens de sorgo analisadas $(\mathrm{P}<0,05)$, com 10,62 $\mathrm{g} \mathrm{kg}^{-1} \mathrm{MS}$ e, entre as amostras de panículas, também revelou o mais alto valor de TC de $37,39 \mathrm{~g} \mathrm{~kg}^{1} \mathrm{MS}$. Diferenças entre silagens de sorgos não foram detectadas para lignina e DIVMS (P > 0,09). O maior conteúdo de proteína foi observado na linhagem CMSXS165 $\left(97,4 \mathrm{~g} \mathrm{~kg}^{-1} ; \mathrm{P}<0,05\right)$. Concentrações de proteína bruta em CMSXS114 (83,2 $\left.\mathrm{g} \mathrm{kg}^{-1}\right)$, BR $700\left(76,4 \mathrm{~g} \mathrm{~kg}^{-1}\right)$, BR701 (80,5 $\left.\mathrm{g} \mathrm{kg}^{-1}\right)$ e AG2005 (79,2 $\left.\mathrm{g} \mathrm{kg}^{-1}\right)$ foram acima da média geral $\left(74,0 \mathrm{~g} \mathrm{~kg}^{-1}\right)$. As duas linhagens isogênicas não foram diferentes para a DIVMS (24 e 48 h). Conclui-se que a digestibilidade in vitro não foi afetada pelo nível de tanino condensado encontrado; entretanto, consideram-se relativamente baixas as concentrações de tanino condensado encontradas devido, ao efeito de diluição dos grãos. Contudo, não foi possível antecipar nenhum efeito significativo do conteúdo de TC no consumo de matéria seca, digestibilidade ou performance em bovinos alimentados com esses materiais ensilados.

Palavras-chave: sorgo, silagem, tanino, proteína bruta, FDN, FDA, IVDMD

Abreviações-chaves: $\mathbf{T C}=$ tanino condensado; $\mathbf{W T}=$ sem tanino, $\mathbf{T}=$ tanino.

In almost every region of the world a period of abundance and another with shortage of forage always occur, even though the food demand remains almost constant. The forages with the best nutritional value for conservation as silages are corn and sorghum (Van Soest, 1994). Sorghum is a good crop choice in the period between harvests in traditional cerealgrowing areas, mainly for its high tolerance to drought (Magalhães \& Rodrigues, 2001). Therefore, one way to improve milk production of cattle is by developing new cultivars of sorghum forage with higher productivity and nutritional value as an alternative to overcome low availability of forage in this period.

Plant breeding programs have produced hybrids with increased grain content to improve silage production and quality. One of the biggest problems in sorghum silage production is its grain content. Since the sorghum plant is prone to bird attack, the amount of grain can fall in the silage, compromising its nutritional quality. To reduce this negative impact, researchers have been producing cultivars with a high content of condensed tannin, which can reduce the palatability to birds of the grain in the panicle. However, condensed tannins in the forage are thought to reduce the nutritional value because historically the belief has been that condensed tannins (CT) are responsible for depressing digestibility of plant material, in addition to decreasing palatability and consumption, depending on its tannin concentration.

In diets of monogastric animals, highly condensed tannin concentrations can reduce protein digestility and absorption and are 
responsible for low digestibility of dry matter. The use of ground sorghum with condensed tannin in the diet of monogastric animals such as young chickens has resulted in decreased consumption and caused deleterious effects such as reduction of amino acid absorption (Rodriguez et al., 1999). However, for ruminants, tannins play a significant role in the nutritional value of feed, causing either adverse or beneficial effects on nutrient use, health and production. The ideal concentration of CT in forage legumes generally ranges from 20-40 g/kg DM, and at this level it may bind with dietary proteins during mastication and protect it from microbial attack in the rumen (Nguyen et $a l ., 2005)$. The superior value of the tannin, as mentioned above, will perhaps reduce the nutritional value and the biological availability of the dietary mineral and protein intake (Barry et al., 1986; Albrecht \& Broderick, 1990,).

Min et al. (2002, 2005) demonstrated that the condensed tannin when grazing animals eat Lotus corniculatus or Lespedeza cuneata could protect proteins in the rumen, releasing them for absorption in the intestine. The hydrophobic part of protein complexes form hydrogen bridges, which interact with the tannin molecules that become unavailable in the rumen and can only be absorbed at the intestinal level. In the case of sorghum, no negative nutritional effect of the condensed tannin has been found in ruminants. In addition, tannin is the substance involved in the plant defense system against diseases and insect attack. Furthermore, condensed tannin can also be an alternative non-drug gastrointestinal parasite control. Strategies have been suggested by Min et al., 2002, 2005, Molan et al., 2000, based on using forages that contain condensed tannins (CT). CT are recognized for their property of forming complexes with soluble ruminal proteins, which reduce the degradation of protein to ammonia in the rumen and allow more dietary protein flow to the small intestine (Barry et al.,1986; Van Soest, 1994, Barry \& McNabb, 1999). This increases the supply of digestible protein in the host (Min et al., 2002) and has an indirect effect on gastrointestinal parasite resistance by enhancing the immune response through improved protein nutrition (MacRae et al., 1993; Barry \& McNabb, 1999).

The objective of this study was to quantify and evaluate the effects of CT on the nutritional quality of the ensilage of sorghum for cattle.

\section{Materials and Methods}

The field experiments for production of silage were carried out at the Embrapa Corn and Sorghum Research Station in Sete Lagoas, Minas Gerais, Brazil, in 2002. Ten genotypes of sorghum were used: two isogenic lines (CMSXS114 and CMSXS165), four hybrids (BR601, BRS701, BR700 and AG2005), two experimental hybrids of high transport (9953101 and 9953130) and two varieties (BR501 and BR506). The two isogenics lines used in this work differing only by the presence of condensed tannin. The Embrapa Corn and Sorghum Research Center has developed these lines exclusively to evaluate the interference of CT in nutritional quality. The experiment was carried out in a completely randomized block design, with ten treatments (genotypes) and eight replications each (PVC silos). The data were submitted to analysis of variance and the means were grouped by the Scott \& Knott, 1974 test (5\%) using Ferreira's (2000) methodology. The sorghum silage was made with three middle lines from five with three meters in length for each silage genotype. When the materials reached the ensiling point (grains at drought stage) they were cut, chopped and ensiled in mini-si- 
los made of PVC with $3 \mathrm{~kg}$ capacity. The silos were opened 60 days afterward. For density standardization, $\left(700 \mathrm{~kg} / \mathrm{m}^{3}\right)$ a press was used to compact the forage in the silos. PVC covers were made with Bunsen valves to eliminate the gases produced by fermentation. Also, samples of the panicles of all genotypes were processed to quantify the condensed tannin. In the Embrapa Dairy Cattle Center laboratories after opening the silos, two samples were taken, one left in the freezer for bromatological analyses and the other lyophilized to quantify the condensed tannin. For quantification of the condensed tannin, along with the samples of ensiled panicles, the Butanol-HCl method (Porter et al., 1986) was used. The quantification was carried out using chromatography with Sephadex column (Sephadex LH-20; Sigma) based on a standard TC-content curve using Quebracho 73\% CT (of the tropical dicotyledon Schinopsis balansae) purification.

\section{Laboratory Analyses}

Some silage were frozen and others were freeze dried and ground to pass through a $1 \mathrm{~mm}$ (for in vitro) in a Wiley mill, for laboratory analyses. The Kjeldahl method was used for crude protein (CP) analysis (Helrich, 1990). Neutral detergent and acid detergent fiber (NDF and $\mathrm{ADF}$ ) and lignin (LIG) were analyzed using the sequential methods of Van Soest et al. (1991). The in vitro dry matter digestibility was assessed using the methods of Tilley \& Terry (1963).

\section{Results and Discussion}

The experimental accuracy of the statistical analyses, measured by the coefficient of variation $(\mathrm{CV})$, was adequate for all characteristics

TABLE 1. Contents (\%) of dry matter (DM), neutral detergent fiber (NDF), acid detergent fiber (ADF), lignin, in vitro dry-matter digestibility (24 and $48 \mathrm{hs)} \mathrm{(IVDMD),} \mathrm{and} \mathrm{crude} \mathrm{protein} \mathrm{(CP)} \mathrm{of}$ some lines, hybrids and varieties of sorghum silage.

\begin{tabular}{llllllll}
\hline Treatments $^{1}$ & \multirow{2}{*}{ \%DM } & NDF & ADF & Lignin & \multicolumn{2}{c}{ IVDMD } & CP \\
\cline { 1 - 3 } & & & & & $\mathbf{2 4 h}$ & $\mathbf{4 8 h}$ & \\
\hline L-CMSXS114 & $32.12 \mathrm{~b}$ & $51.19 \mathrm{a}$ & $36.22 \mathrm{~b}$ & $13.31 \mathrm{a}$ & 56.87 & 60.39 & $83.2 \mathrm{~b}$ \\
L-CMSXS165 & $29.95 \mathrm{~b}$ & $52.65 \mathrm{a}$ & $33.99 \mathrm{a}$ & $11.40 \mathrm{a}$ & 55.19 & 57.88 & $97.4 \mathrm{a}$ \\
H-9953101 & $29.08 \mathrm{~b}$ & $57.90 \mathrm{c}$ & $39.00 \mathrm{c}$ & $17.08 \mathrm{~b}$ & 54.45 & 59.23 & $70.1 \mathrm{c}$ \\
H-9953130 & $26.75 \mathrm{c}$ & $52.90 \mathrm{a}$ & $33.94 \mathrm{a}$ & $11.69 \mathrm{a}$ & 52.96 & 58.90 & $72.8 \mathrm{c}$ \\
H-BR601 & $22.29 \mathrm{e}$ & $58.92 \mathrm{c}$ & $38.51 \mathrm{c}$ & $10.28 \mathrm{a}$ & 53.48 & 56.59 & $68.3 \mathrm{c}$ \\
H-BR701 & $38.73 \mathrm{a}$ & $55.67 \mathrm{~b}$ & $38.67 \mathrm{c}$ & $12.75 \mathrm{a}$ & 56.49 & 60.84 & $80.5 \mathrm{~b}$ \\
H-BR700 & $39.57 \mathrm{a}$ & $54.31 \mathrm{~b}$ & $34.70 \mathrm{a}$ & $11.63 \mathrm{a}$ & 56.49 & 59.93 & $76.4 \mathrm{~b}$ \\
V-BR501 & $25.58 \mathrm{~d}$ & $55.91 \mathrm{~b}$ & $36.90 \mathrm{~b}$ & $11.78 \mathrm{a}$ & 53.36 & 58.89 & $62.2 \mathrm{~d}$ \\
V-BR506 & $21.45 \mathrm{e}$ & $62.09 \mathrm{~d}$ & $40.55 \mathrm{c}$ & $10.65 \mathrm{a}$ & 54.91 & 59.07 & $51.9 \mathrm{e}$ \\
H-AG2005 & $38.50 \mathrm{a}$ & $53.00 \mathrm{a}$ & $34.97 \mathrm{a}$ & $11.19 \mathrm{a}$ & 54.75 & 56.40 & $79.2 \mathrm{~b}$ \\
\hline CV(\%) & 9.91 & 5.34 & 5.22 & 32.31 & 6.05 & 6.06 & 6.38 \\
\hline Mean & 31.23 & 55.35 & 36.55 & 12.12 & 55.22 & 59.01 & 74.2 \\
\hline
\end{tabular}

${ }^{1}$ Different letters in the same column indicate significant differences between averages of the treatments, for the ScottKnott test at $5 \%$ probability (Scott \& Knott, 1974). Protein equal $\mathrm{g} / \mathrm{kg}^{-1} \mathrm{~L}=$ ancestry; $\mathrm{H}=$ hybrid; $\mathrm{V}=$ variety. 
evaluated, with the exception of the lignin percentage (Table 1), suggesting the results obtained were trustworthy. Significant differences among the sorghum genotypes for condensed tannin concentration in the silage and panicle, percentage of DM, CP, NDF, ADF and lignin were observed, showing the existence of genetic variability in the species for these nutritional characteristics (Table 1). Rodriguez et al., (1999) and Gonçalves et al., (1999), also reported similar results. These results indicate sorghum-breeding programs aiming at improving the quality of the plants produced by these species may be successful. Average condensed tannin concentrations in silages were divided into four groups for the Scott-Knott test, varying from $1.8 \mathrm{~g} \mathrm{CT} / \mathrm{kg}$ of dry matter in silage of line CMSXS165 to $10.62 \mathrm{~g} \mathrm{CT/}$ $\mathrm{kg}$ in silage of hybrid 9953130. The average concentration in panicles was $18.34 \mathrm{~g}$ of condensed tannin per kg of dry matter, and also formed four groups of means (Table 2). The average percentage of dry matter in silage was $31.2 \%$, with variation amplitude of $18.13 \%$. The genotypes were grouped in five sets for the Scott-Knott test, with hybrids BRS701, BR700 and AG2005 having higher dry matter contents.

The differences in dry matter content were related to the type of material, since lower dry matter contents were observed with sweet sorghums that have succulent culms (hybrid BR601 and varieties BR501 and BR506). Other genotypes had dry culms. Hybrids 9953101 and 9953130, as the other treatments, also had dry culms with high dry matter content. The averages of NDF, ADF and lignin were 55.3, 36.5 and $7.5 \%$, and the genotypes divided into 4,3 and 2 groups, respectively. CP showed five mean groups in the Scott-Knott test. The CMSXS165 line was the highest in CP percentage $(9.74 \%)$ and the BR506 variety was the lowest (5.19\%).
The silage with more grains had higher $\mathrm{CP}$, the same was observed by Moline et al., (2002). The in vitro digestibility averages for 24 and 48 hours varied from $55.2 \%$ to $59 \%$ and were statistically similar $(\mathrm{P}>0,05)$. The results of chemical analyses agree with those on the nutritional quality of sorghum forage of Gonçalves et al., (1999). On the other hand, the condensed tannin in silages can form complexes with the protein fraction, reducing its degradability and consequently its availability (Van Soest, 1994). Moreover, the condensed tannin can cause cellulolytic and ureolytic bacterial enzyme inhibition (Kumar \& Singh, 1984; Marinho, 1984) as well as alterations among the acids in the rumen fermentation processes (Van Hoven \& Furstenburg, 1992). In fact,

TABLE 2. Percent of condensed tannin (CT) in lines, hybrids and varieties of sorghum silage and respective panicles (dry matter basis).

\begin{tabular}{lll}
\hline Treatments $^{\mathbf{1}}$ & $\begin{array}{l}\text { CT } \\
\text { Silage }\end{array}$ & $\begin{array}{l}\text { CT } \\
\text { Panicle }^{\mathbf{1 , 2}}\end{array}$ \\
\hline L-CMSXS114 & $7.84 \mathrm{Ac}$ & $29.42 \mathrm{Bc}$ \\
L-CMSXS165 & $1.80 \mathrm{Aa}$ & $0.26 \mathrm{Aa}$ \\
H-9953101 & $10.59 \mathrm{Ad}$ & $37.39 \mathrm{Bd}$ \\
H-9953130 & $10.62 \mathrm{Ab}$ & $17.11 \mathrm{Bb}$ \\
H-BR601 & $1.54 \mathrm{Aa}$ & $1.07 \mathrm{Aa}$ \\
H-BR701 & $6.29 \mathrm{Ac}$ & $29.19 \mathrm{Bc}$ \\
H-BR700 & $9.13 \mathrm{Ac}$ & $28.42 \mathrm{Bc}$ \\
V-BR501 & - & - \\
V-BR506 & - & - \\
H-AG2005 & $2.21 \mathrm{Aa}$ & $3.87 \mathrm{Aa}$ \\
\hline AVERAGE & 7.59 & 18.34 \\
\hline
\end{tabular}

${ }^{1}$ Different letters in the same line (upper case) indicate significant differences between averages of the treatments, for the Scott-Knott test at $5 \%$ probability. ${ }^{2}$ Different letters in the column (lower case) indicate significant differences between averages of treatments for the same test. $\mathrm{L}=$ ancestry; $\mathrm{H}=$ hybrid; $\mathrm{V}=$ variety. 
Albrecht \& Muck (1991), studying the fermentative aspects of leguminous silages, observed that condensed tannin inhibited proteolysis. The same was observed by Borges (1995) and Rodriguez et al. (1999). Moreover, these are sufficiently close to the results obtained for NDF, ADF and CP in corn silage by Silva et al., (2003). They found similar nutritional value for corn and sorghum silages. The biggest restriction to the use of sorghum for silage production is its susceptibility to bird attack when the grain is mature, reducing significantly protein percentage of the silage. The strategy to prevent this attack has been to aggregate genetic materials with higher content of condensed tannin in the grain, reducing its palatability to birds. However, doubts still exist regarding the negative effects of condensed tannin on silage's quality. In this study, we observed that the genetic materials with lower condensed tannin concentrations in the silage (L-CMSXS165, H-BR601 and H-AG2005) presented similar IVDMD in relation to the other genotypes evalu- ated. The L-CMSXS165 lines and H-AG2005 hybrid, for example, ranked better in the means test for almost all characteristics evaluated (Figure 1). This result, however, cannot be totally related to the effect of the condensed tannin, so the different genetic backgrounds must be involved. The only way to isolate the effect of the condensed tannin is to use isogenic lines for this characteristic, i.e. lines that only differ among themselves in relation to the presence or not of condensed tannin. Table 1 also shows that isogenics lines L-CMSXS114 and L-CMSXS165 differed greatly for condensed tannin concentrations. Lines L-CMSXS114 presented roughly four times the condensed tannin than their similar line (L-CMSXS165) in the silage and panicle respectively. For all characteristic evaluated, the two lines were statistically similar $(\mathrm{P}<0,05)$, except for $\mathrm{CP}$ and ADF, showing that the process of obtaining the isogenics lines was efficient. The line with the higher condensed tannin concentration performed sufficiently close to its isogenic

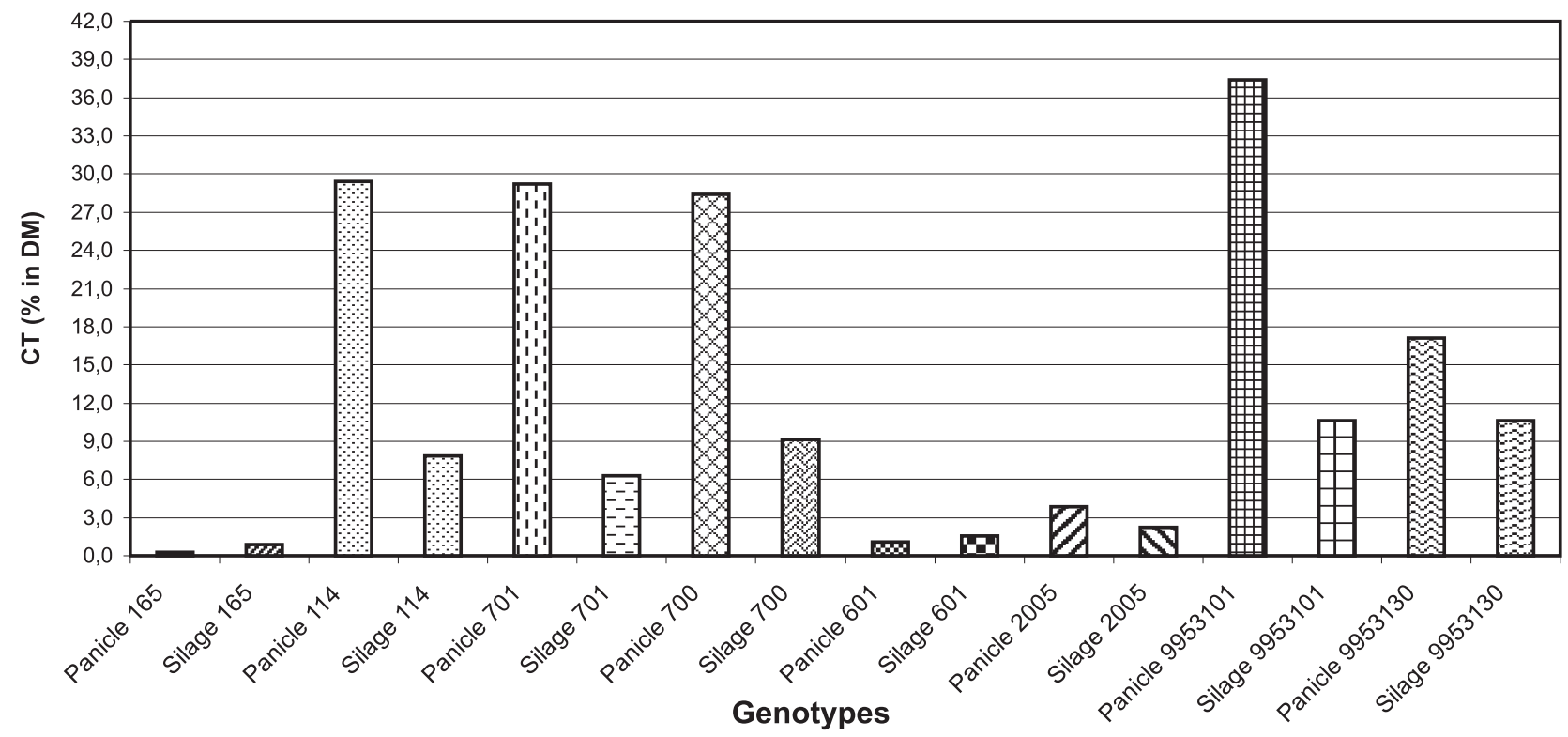

FIGURE 1. Condensed tannin concentrations ( $\%$ in DM) in silage of sorghum and respective panicles of some lines, hybrids and varieties of sorghum. 
line without condensed tannin, indicating that at that concentration the condensed tannin did not affect the nutritional quality of sorghum forage. These results agree with the affirmation that condensed tannin concentrations below 40 $\mathrm{g} / \mathrm{kg}$ of dry matter do not interfere with the digestion, absorption and use of nutrients of silages by ruminants. Min et al., (2005) in their review paper, found that diets with tannin concentrations of 20 to $40 \mathrm{~g} \mathrm{~kg}^{-1}$ of dry matter, enhance the nutritive value, as well as the productive and sanitary performance, of grazing Lotus pedunculatus and Lotus corniculatus, improving daily weight gain and sanitary and productive aspects, probably because of higher protein availability.

The majority of genotypes available in the market has CT concentration higher than those found in the genotypes evaluated in this experiment, which are around the stipulated maximum limit, for feeding ruminants without negative effects on nutritional value. When one considers the condensed tannin concentrations in the panicle, they are still lower than the recommendation in the literature, indicating that the grain can be used as silage without great nutritional problems for ruminants. These results show that condensed tannin found at the contents was not related to lower forage digestibility. However at higher level, it is recognized as an anti-nutritional factor (Rodriguez et al., 1999).

To evaluate the interference of condensed tannin in the nutritional quality of sorghum silage of genotypes with high concentrations of this element, in vivo trials should be carried out with the two isogenics lines CMSXS114 and CMSXS165.

Since no interference of condensed tannin concentrations (lower than $10,62 \mathrm{~g} / \mathrm{kg}^{-1}$ ) was shown in the IVDMD of silages of the evaluated sorghum genotypes, they can be recommended for silage production.

\section{Conclusions}

The results show that silage of different sorghum genotypes with condensed tannin contents lower than $10,62 \%$ did not affect their in vitro dry matter digestibility and can be fed to ruminants without adverse effects as sorghum silage without condensed tannin.

\section{Literature Cited}

ALBRECHT, K. A.; BRODERICK, G. A. Degradation of forage legume protein by rumen microorganisms. Agronomy Abstracts. Madison, p.123, 1990.

ALBRECHT, K. A.; MUCK, R. E. Proteolysis in ensiled forage legumes that vary in tannin concentration. Crop Science, v. 31, p. 464-469, 1991.

BARRY, T. N.; McNABB, T. R. The implications of condensed tannins on the nutritive value of temperate forages fed to ruminants. British Journal of Nutrition, Cambridge, v. 81, p. 263272, 1999.

BARRY, T. N.; MANLEY, T. R.; DUNCAN, S. J. The role of condensed tannins in the nutritional value of Lotus pendunculatus for sheep. British Journal of Nutrition, Cambridge, v. 55, p. 123-137, 1986.

BORGES, A. L. C. C. Qualidade de silagens de híbridos de sorgo de porte alto com diferentes teores de tanino e de umidade no colmo, e seus padrões de fermentação. 1995. $104 \mathrm{f}$. Tese (Mestrado) - Universidade Federal de Minas Gerais, Belo Horizonte.

FERREIRA, D. F. Análise estatística por meio do SISVAR para Windows: Versão 4.0. In: REU- 
NIÃO ANUAL DA REGIÃO BRASILEIRA DA SOCIEDADE INTERNACIONAL DE BIOMETRIA, 45., 2000, São Carlos. Anais... São Carlos: SSP/SIB, 2000. p. 255-268.

GONÇALVES, L. C.; RODRIGUEZ, N. M.; NOGUEIRA, F. S.; BORGES, A. L. C. C.; ZAGO, C. P. Silagens de sorgo de porte alto com diferentes teores de tanino e umidade no colmo. III Quebra de compostos nitrogenados. Arquivo Brasileiro de Medicina, Vetetrinária e Zootecnia, Belo Horizonte, v. 51, p. 161-165, 1999.

HELRICH, K. Official methods of analysis of the Association of Official Analytical Chemists. 15. ed. Arlington: AOAC, 1990.

KUMAR, R.; SINGH, M. Tannins: their adverse role in ruminant nutrition. Journal of Agricultural and Food Chemistry, Washington, v. 32, p. 447-453, 1984.

MAGALHÃES, P. C.; RODRIGUES, J. A. S. Fisiologia da produção do sorgo forrageiro. In: CRUZ, J. C.; PEREIRA FILHO, I. A.; RODRIGUES, J. A. S.; FERREIRA, J. J. (Eds.). Produção e utilização de silagem de milho e sorgo. Sete Lagoas: Embrapa Milho e Sorgo, 2001. p. 227-241.

MARINHO, A. A. M. Influência dos taninos no comportamento dos microrganismos e sua implicações nas transformações microbianas no trato gastrointestinal dos ruminantes. Revista Portuguesa de Ciências Veterinarias, Lisboa, ,v. 79, p. 5-21, 1984.

MIN, B. R.; ATTWOOD, K.; REILLY, W.; SUN, J. S.; PETERS, T.; BARRY, N.; MCNABB, W. C. Lotus corniculatus condensed tannins decreased in vivo population of proteolytic bacteria and affect nitrogen metabolism in the rumen of sheep.
Canadian Journal of Microbiology, Ottawa, v. 48, p. 911-921, 2002.

MIN, B. R.; HART, S. P.; MILLER, A, B, G. M. TOMITA,G. M.; LOETZ, A.; SAHLU, T. The effect of grazing forage containing condensed tannins on gastro-intestinal parasite infection and milk composition in Angora does. Veterinary Parasitology, Amsterdam, v. 130, p. 105-113, 2005.

MOLINA, L. R.; GONÇALVES, L. C.; RODRIGUEZ, M. N.; RODRIGUES, J. R. S.; FERREIRA, J. J. NETO, A. G. de C. Degradabilidade in situ da matéria seca e proteína bruta das silagens de seis genótipos de sorgo (Sorghum bicolor (L) Moench) em diferentes estádios de maturação. Revista Brasileira de Zootecnia, Viçosa, v. 31, n.1, p.148-156, 2002.

MOLAN, A. L.; WAGHORN, G. C.; MIN, B. R.; MCNABB, W. C. Condensed tannins and gastrointestinal parasites in sheep. Proceedings of the New Zealand Grassland Association, Palmerston, v. 61, p. 57-61, 2000.

MAcRAE, R.; ROBINSON, R. K.; SADLER, M. J. Encyclopedia of Food Science, Food Technology, and Nutrition. San Diego: Academic Press, 1993. v. 7, p. 4828-4834.

NGUYEN, T. M.; BINH, D. V.; ORSKOV, E. R. Effect of foliages containing condensed tannin and on gastrointestinal parasites. Animal Feed Science and Tecnology, Amsterdam, v. 121, n.12, p.77-87, 2005.

PORTER, L. J.; HRSTICH, L. N.; CHAN, B. G. The Conversion of proanthocyaniding and prodelphinidins to Cyanidin and Delphinidin. Phytochemistry, Elmsford, v. 25, n. 1, p. 223230, 1986.

RODRIGUEZ, N. M.; BORGES, A. L. C. C.; NOGUEIRA, F. S.; GONÇALVES, L. C. I.; 
BORGES, L. Silagens de sorgo de porte baixo com diferentes teores de tanino e umidade no colmo. IV - Influencia dos taninos sobre a digestibilidade in vitro da matéria seca. Arquivo Brasileiro de Medicina Veterinaria e Zootecnia, Belo Horizonte, v. 51, n. 6, p. 577-582, 1999.

SILVA, P. C. ; AYALA-OSUNA, J. T. ; MORO, J. R. ; PAIVA, L. M. ; QUEIROZ, S. R. ${ }^{\circ}$ D. ; MARTINS, M. R. Avaliação de híbridos interpopulacionais de milho quanto as características químicas e agronômicas para silagem. Revista Brasileira de Milho e Sorgo, Sete Lagoas, v. 2, n.3, p.111-120, 2003.

SCOTT, A. J.; KNOTT, M. A. A cluster analyses method for grouping means in the analysis of variance. Biometrics, Washington, v. 30, n. 3, p. 507-512, Sept. 1974.

TILLEY, M. A.; TERRY, R. A. A two-stage technique for the in vitro digestion of forage crops. Journal of the British Grassland Society, Oxford, v. 18, p. 104-111, 1963.

VAN SOEST, P. J.; ROBERTSON, J. B.; LEWIS, B.A. Methods for dietary fiber, neutral detergent, and nonstarch polysaccharides in relation to animal nutrition. Journal of Dairy Science, Champaign, v. 74, n. 10, p. 3583-3597, 1991.

VAN SOEST, P. V. Nutritional ecology of the ruminant. 2.ed. Ithaca: Cornell University Press, 1994. 476 p. 